\title{
Changes in gonadotrophin concentrations are not necessarily involved in ovarian compensation after unilateral ovariectomy in sheep
}

\author{
R. C. Fry, I. J. Clarke* and L. P. Cahill \\ Animal Research Institute, Werribee, Victoria 3030, and*Medical Research Centre, \\ Prince Henry's Hospital, Melbourne, Victoria 3004, Australia
}

\begin{abstract}
Summary. Ewes were unilaterally ovariectomized and/or hypophysectomized and treated with PMSG and hCG. For a given gonadotrophin treatment the ovulation rate per ewe was maintained, i.e. the ovulation rate of the remaining ovary was significantly increased $(P<0.05)$, after the removal of one ovary in hypophysectomized and in pituitary-intact ewes. It is concluded that compensation of ovulation rate in the remaining ovary after unilateral ovariectomy in the sheep may be independent of feedback from the ovary and the release of gonadotrophins from the pituitary gland.
\end{abstract}

\section{Introduction}

It was noted as early as 1787 by John Hunter that the removal of one ovary does not affect litter size in pigs. Since then this phenomenon has been demonstrated for animals of other species including the mouse (Jones \& Krohn, 1960), rat (Peppler \& Greenwald, 1970), hamster (Hermreck \& Greenwald, 1964), cow (Saiduddin et al., 1970) and sheep (Land, 1973).

Land (1973) found that unilateral ovariectomy performed as late as Day 14 of the oestrous cycle in sheep did not affect the ovulation rate at the subsequent oestrus and a doubling of the number of ovulations had occurred in the remaining ovary. It has been suggested that this compensation of ovulation rate may result from a decrease in the amount of follicular atresia (Hirshfield, 1982) and/or an increase in the amount of follicular recruitment (Meijs-Roelofs et al., 1984), but the mechanisms involved in these responses are still unclear. The growth and development of growing follicles is dependent upon gonadotrophin support from the pituitary gland and many previous studies have investigated changes in the gonadotrophin, ovarian steroid and protein concentrations in blood plasma after unilateral ovariectomy. Another possibility is that compensation is independent of feedback between the ovary and the release of gonadotrophins from the pituitary gland. As it is not feasible to control the level of pituitary gonadotrophins in the peripheral blood plasma we tested whether compensation is affected by the 'supply' of exogenous gonadotrophins in hypophysectomized animals.

\section{Materials and Methods}

Mature parous Border-Leicester $\times$ Merino ewes in good condition were induced to ovulate by treatment with exogenous gonadotrophins after random allocation to four treatment groups: Group l consisted of 6 entire ewes, 6 ewes in Group 2 were unilaterally ovariectomized, the 6 ewes in Group 3 were hypophysectomized and 6 ewes in Group 4 were unilaterally ovariectomized and hypophysectomized. Oestrous cycles were synchronized using intravaginal progestagen-impregnated sponges (Repromap: Upjohn, Rydalmere, Australia) for 12 days before surgery.

For surgery, anaesthesia was induced with thiopentone sodium (Intraval: May and Baker, Footscray, Australia) and maintained with a halothane-oxygen mixture. For hypophysectomy the ewes were positioned with their heads firmly held by a metal framework. The dura mater along the anterior face of the pituitary was exposed by a transnasal, trans-sphenoidal route described in detail by Clarke et al. (1983). The dura mater was opened and the pituitary stalk 
was sectioned by diathermy. The pituitary gland was removed by blunt dissection and soft suction with metal suckers. The empty fossa was swabbed with alcohol to kill any remaining endocrine cells. The fossa was packed with gelatin foam (Gelfoam, size 4; Upjohn) and sealed with dental acrylic (R.D. Dental Acrylic; De Trey, Cambridge, U.K.) before replacement of the frontal and nasal bones. It was later confirmed, using a GnRH and TRH challenge, to induce the release of any pituitary hormones, that no pituitary activity remained in these ewes.

Unilateral ovariectomy was performed immediately after hypophysectomy by exteriorizing the uterus through a mid-ventral abdominal incision. In each ewe, the ovary to be removed was chosen at random. After surgery intravaginal sponges were removed and the sheep were injected (i.m.) with 500 i.u. PMSG (Folligon; Intervet, Lane Cove, Australia) and with 250 i.u. PMSG 24 h later. All ewes were injected (i.m.) with 750 i.u. hCG (Chorulon; Intervet) 56 h after sponge removal to stimulate ovulation. The ovulation rate (number of ovulations per ewe) was determined by noting the number of corpora lutea on the ovaries at laparoscopy, which was performed under local anaesthesia $90 \mathrm{~h}$ after sponge removal.

The number of ovulations was compared using ANOVA for treatment effects and interactions. Differences amongst groups were established by Duncan's Multiple Range Test.

\section{Results}

As shown in Table 1, ovulation was induced in all groups; no ewe had more than 2 ovulations in Group 3 and 4 but those in Groups 1 and 2 had 1-6 ovulations. In the unilaterally ovariectomized ewes (Groups 2 and 4 ) ovulation rate per ovary was significantly increased.

Blood samples taken 4 weeks after hypophysectomy showed undetectable concentrations of circulating FSH, LH and prolactin, and no response to the GnRH and TRH challenges, thus indicating that the hypophysectomy was complete.

Table 1. Mean ( \pm s.e.m.) ovulation rate (as CL) of ewes $34 \mathrm{~h}$ after hCG injection and after hypophysectomy (hypox.) and/or unilateral ovariectomy (ULO)

\begin{tabular}{ccccc}
\hline & $\begin{array}{c}\text { Group 1 } \\
\text { (entire) }\end{array}$ & $\begin{array}{c}\text { Group 2 } \\
\text { (ULO) }\end{array}$ & $\begin{array}{c}\text { Group 3 } \\
\text { (hypox.) }\end{array}$ & $\begin{array}{c}\text { Group 4 } \\
\text { (hypox. + ULO) }\end{array}$ \\
\hline $\begin{array}{c}\text { No. of ewes } \\
\text { ovulating }\end{array}$ & $6 / 6$ & $6 / 6$ & $5 / 6$ & $4 / 6$ \\
$\begin{array}{c}\text { CL per ewes } \\
\text { ovulating }\end{array}$ & $2 \cdot 3 \pm 0 \cdot 33$ & $3 \cdot 0 \pm 0.81$ & $1 \cdot 8 \pm 0 \cdot 20$ & $1 \cdot 8 \pm 0 \cdot 25$ \\
CL per ovary & $1 \cdot 2^{\mathrm{a}}$ & $3 \cdot 0^{\mathrm{c}}$ & $0 \cdot 9^{\mathrm{a}}$ & $1 \cdot 8^{\mathrm{b}}$ \\
\hline
\end{tabular}

Different superscripts denote significant differences $(P<0 \cdot 05)$.

\section{Discussion}

In this study gonadotrophin treatment to hypophysectomized ewes induced the same ovulation rate per ewe regardless of the number of ovaries, and so compensation of ovulation rate still occurs in such ewes even without an alteration to the gonadotrophin supply. This indicates that the ovaries may communicate directly in hypophysectomized gonadotrophin-treated sheep. Failure of hypophysectomized rats to show compensation in ovarian weight (Greenwald, 1968) or ovulation rate (Welschen, 1972) after unilateral ovariectomy suggests that the mechanism involved in ovarian compensation may differ between animal species or between mono- and poly-ovulators. In the light of our results this difference between species may require further investigation.

A small transient elevation in plasma FSH concentrations has been observed after unilateral ovariectomy in ewes (Findlay \& Cumming, 1977), rats (Butcher, 1977), hamsters (Bast \& Greenwald, 1977), gilts (Redmer et al., 1984) and heifers (Johnson et al., 1985). It has been suggested that the mechanism causing compensatory ovarian hypertrophy involves an increased gonadotrophin 
secretion due to decreased negative feedback because of the lower blood oestrogen concentrations after the removal of one ovary (Greenwald, 1968). These higher gonadotrophin concentrations after unilateral ovariectomy may be due to feedback effects but are unlikely to be the causative factors for the subsequent compensatory ovulation as we have demonstrated that, in hypophysectomized ewes receiving an equal dose of exogenous gonadotrophin, compensation of ovulation rate after unilateral ovariectomy occurred such that the ovulation rate per ewe was maintained. This response was consistent with that observed in the pituitary-intact ewes and the exogenous hormonal regimens gave an ovulation rate in most hypophysectomized ewes that was very close to that seen in the untreated cross-bred ewe (Cumming, 1972, 1977). We therefore consider that the dose of gonadotrophin was sufficient to give a physiological response.

In searching for other theories to explain the compensatory ovarian response, studies investigating the effect of spinal cord transection (Gelderd \& Peppler, 1979) and sympathetic denervation of the ovaries (Wylie et al., 1984) on the reproductive system in the female rat indicated that changes in the neural signals between the hypothalamus and ovaries were not involved. This requires verification in the sheep. Greenwald (1972) demonstrated that the destruction of follicles in one ovary of pregnant hamsters by X-irradiation resulted in compensatory growth of follicles in the non-irradiated ovary, which suggests that the follicle is the source of the material responsible for the control of ovarian compensation after unilateral ovariectomy. Johnson et al. (1985) have shown that the administration of charcoal-extracted bovine follicular fluid to prepubertal heifers will prevent compensatory ovarian hypertrophy. It is therefore attractive to consider that follicular growth inhibitors that act locally on the ovary (Cahill et al., 1984) may be involved in an interovarian mechanism to control ovulation rate. Such an hypothesis would require that the two ovaries communicate, possibly via the blood stream.

We thank Mr T. Gill for help with radioimmunoassays and $\mathrm{Mr}$ P. Weston for technical assistance. This study was funded by the Wool Research Trust Fund of the Australian Wool Corporation.

\section{References}

Bast, J.D. \& Greenwald, G.S. (1977) Acute and chronic elevations in serum levels of FSH after unilateral ovariectomy in the cyclic hamster. Endocrinology 100, 955-966.

Butcher, R.L. (1977) Changes in gonadotropins and steroids associated with unilateral ovariectomy in the rat. Endocrinology 101, 830-840.

Cahill, L.P., Clarke, I.J., Cummins, J.T., Driancourt, M.A., Carson, R.S. \& Findlay, J.K. (1984) An inhibitory action at the ovarian level of ovine follicular fluid on PMSG-induced folliculogenesis in hypophysectomized ewes. In Proceedings of the 5th Ovarian Workshop, pp. 35-38. Eds D. O. Toft \& R. J. Ryan. Ovarian Workshops, Champaign, Illinois.

Clarke, I.J., Cummins, T.J. \& de Kretser, D.M. (1983) Pituitary gland function after disconnection from direct hypothalamic influences in the sheep. Neuroendocrinology 36, 376-384.

Cumming, I.A. (1972) The effects of increasing and decreasing liveweight on ovulation and embryonic survival in the Border Leicester $\times$ Merino ewe. Proc. Aust. Soc. Anim. Prod. 9, 192-198.

Cumming, I.A. (1977) Relationships in the sheep of ovulation rate with liveweight, breed, season and plane of nutrition. Aust. J. exp. Ag. Anim. Husb. 17, 234-241.
Findlay, J.K. \& Cumming, I.A. (1977) The effect of unilateral ovariectomy on plasma gonadotropin levels, estrus and ovulation rate in sheep. Biol. Reprod. 17, 178-183.

Gelderd, J.B. \& Peppler, R.D. (1979) Effect of spinal cord transection on the reproductive system in the female rat. Neuroendocrinology 29, 293-299.

Greenwald, G.S. (1968) Influence of one or two ovaries on ovulation and ovarian weight in the hypophysectomized rat. Endocrinology 82, 591-596.

Greenwald, G.S. (1972) Effects of X-irradiation on ovarian function in the pregnant hamster. Endocrinology 91, 75-86.

Hermreck, A.S. \& Greenwald, G.S. (1964) The effects of unilateral ovariectomy on follicular maturation in the guinea pig. Anat. Rec. 148, 171-176.

Hirshfield, A.N. (1982) Follicular recruitment in longterm hemicastrate rats. Biol. Reprod. 27, 48-53.

Hunter, J. (1787) An experiment to determine the effect of extirpating one ovarium upon the number of young produced. Phil. Trans. R. Soc. 77, 233.

Jones, E.C. \& Krohn, P.L. (1960) The effect of unilateral ovariectomy on the reproductive lifespan of mice. $J$. Endocr. 20, 129-134.

Johnson, S.K., Smith, M.F. \& Elmore, R.G. (1985) Effect of unilateral ovariectomy and injection of bovine 
follicular fluid on gonadotropin secretion and compensatory ovarian hypertrophy in prepubertal heifers. J. Anim. Sci. 60, 1055-1060.

Land, R.B. (1973) Ovulation rate in Finn-Dorset sheep following unilateral ovariectomy or chlorpromazine treatment at different stages of the oestrous cycle. $J$. Reprod. Fert. 33, 99-105.

Meijs-Roelofs, H.M.A., Kramer, P., Osman, P. \& Sander, H.J. (1984) Compensatory ovulatory mechanisms operative after first ovulation in rats unilaterally ovariectomized prepubertally. Biol. Reprod. 32, 44-51.

Peppler, R.D. \& Greenwald, G.S. (1970) Influence of unilateral ovariectomy on follicular development in cycling rats. Am. J. Anat. 127, 9-14.

Redmer, D.A., Christenson R.K., Ford, J.J. \& Day, B.N. (1984) Effect of follicular fluid treatment on follicle stimulating hormone and compensatory ovarian hypertrophy in prepubertal gilts. Biol. Reprod. 32, 1I1-119.
Saiduddin, S., Rowes, R.F. \& Casida, L.E. (1970) Ovarian follicular changes following unilateral ovariectomy in the cow. Biol. Reprod. 2, 408-412.

Welschen, R. (1972) Effect of unilateral ovariectomy on follicular growth in hypophysectomized rats treated with pregnant mare serum gonadotrophin. $J$. Endocr. 55, 227-228.

Wylie, S.N., Roche, P.J. \& Gibson, W.R. (1984) Ovulation after sympathetic denervation of the rat ovary produced by freezing its nerve supply. J. Reprod. Fert. 75, 369-373.

Received 3 April 1986 